\title{
Evaluating Total Logistics Costs at Macro and Micro Level: Literature Review
}

\author{
Kawtar Akoudad \\ PhD student, \\ Laboratory of Manufacturing, \\ Energy and Sustainable Development, \\ Superior School of Technology, Road of Imouzzer - BP: \\ 2427-Fez, Morocco,
}

\begin{abstract}
The purpose of this work is to establish a literature review about the evaluation of logistics costs at the micro and macro levels. We have developed this problem by addressing at first the importance and difficulties of assessing the logistics cost. Then we have discussed the logistics cost structure. Lastly we have tried to approach in a non-exhaustive way all the logistics cost evaluating methods according to two evaluation levels micro and macro.
\end{abstract}

Keywords-Evaluation; logistics; costs; Macro; Micro; level

\section{INTRODUCTION}

The Logistic plays a crucial role both at the micro and macroeconomic level. Given the complexity of supply chains, and globalization, and due to the changes that have taken place in the productive systems, the manufacturing and labor costs have been significantly reduced. While the logistics costs share has experienced a great increase (up to half of the value of commodities). Reducing these costs has become an increasingly important task for managers. At the macroeconomic level the logistics costs are regarded as one of the main factors influencing competitiveness, policy development, infrastructure development and other investments [1].

Logistic costing is complex even at the micro level, and in the national context very few attempts have been made which explains why the subject has been little covered in the research literature.

Our contribution through this article consists of an extension of literature reviews dealing with the assessment of logistics costs. Specifically, our contribution is that we are dealing with this issue by considering the micro and macro aspects these costs.

Thus, we have addressed the subject by referring, first, the importance and difficulties of assessing logistics costs. These costs, which are as important to managers as to public parties, are difficult to assess. This is largely due to the complexity of logistics activities and the dispersion and difficulties in obtaining relevant information.

In the second place, we have discussed the structure of logistic costs. These costs can be classified, at the micro level, through activities / functions or by cost type from an accounting management point of view.

\author{
Fouad Jawab \\ Professor \\ Laboratory of International Management \\ Decision-Making and Logistics Techniques, \\ Superior School of Technology, Road of Imouzzer- - BP: \\ 2427-Fez, Morocco,
}

In a last place, we have tried to approach in a non-exhaustive way all the logistic costs evaluating methods according to the two evaluation levels micro and micro.

\section{IMPORTANCE AND DIFFICULTIES OF LOGISTICS COSTS EVALUATION}

\section{A. Importance of Logistics Cost Assessement}

The evaluation of logistics costs is of great importance. Thus, flow optimization and resource integration can only take place if managers have transparent information on logistics costs at all stages of the product flow. Without this information, it is impossible to measure the impact of cost decisions along the supply chain [2]. Also, as we know, lowering the product price is a competitive advantage which could lead to an increase in its market share and since logistical costs constitutes a significant fraction of the product price; it is very important to calculate these costs and try to reduce them. Similarly, the contribution of logistical costs to the price level differs from one product to another. Therefore, the calculation of these costs form a good indicator for prioritizing investments in reduced logistics costs in different products.

At the macroeconomic level, logistics cost measurement is considered an appropriate indicator for the past and the future. As future indicator, measuring logistics costs would support the development of national policy and the targeted deployment of operational resources and capital (investment in transport infrastructure). As a past indicator, it will measure performance and pave the way for corrective action.

\section{B. Difficulties in evaluating logistics costs}

The calculation of logistics costs is a complex process, even in entities at the micro level. It should be noted that in the macro context there are only a few attempts to make such assessments [3].

Farahani, Asgari, and Davarzani were able to identify the main factors explaining the complexity of the evaluation and analysis of logistics costs. Firstly, logistics activities are very complex and involve many different processes, not to mention the difficulty of gaining transparent information about these processes [1]. In addition, calculating the depreciation of all goods and equipment involved in logistics activities increases this complexity. 
In addition to these factors, business strategies and operational choices add complexity to macro-level cost measurement. These choices can cause inhibitors of costs transparency, leading to a deficiency in the information, to a narrow view of cost management or differences in allocation of indirect costs [4]. Rantasila gives an example of these choices that have a significant effect on perceived logistical costs [3]. It is indeed the strategy of outsourcing of logistics operations. According to this author, it is essential to know whether the costs of outsourcing are perceived as a part of logistics costs or not. In addition, by outsourcing several functions as a package, the cost of an individual function can be difficult to determine. Also according to the same author, and in parallel with outsourcing, another key issue for measuring logistics costs is the way the company organizes its upstream and downstream logistics. This defines the logistics functions whose costs are covered by the company. One way to recognize a company's share of logistics costs in an international context is to look at delivery terms (incoterms). For example, if a company buys its raw product in Ex work (EXW) and delivers products by Delivery Duty Paid (DDP), it can support greater logistical costs than a company that has organized its logistics in reverse.

\section{STRUCTURE OF LOGISTICS COSTS}

One of the first attempts to classify national logistics costs was made by Dimitrov in 1991. Dimitrov proposes four components of logistics costs: transport costs, commercial costs, communication costs and storage costs [5]. The Logistics and Distribution Management Manual of [6] also provides a five-level breakdown. The fifth level of costs added to the [7] classification is the overall logistic costs. [6] Christopher also identifies some similar cost elements in a study of logistic costing principles. It pays much attention to actual inventory costs and identifies, among other things, inventory control costs [3].

A typical supply chain management perspective is to classify logistics costs across activities or through chain functions (i.e. purchase or warehousing). From an accounting management point of view, this is less common, since it often uses a cost type classification.

\section{A. Logistics costs Components by activities}

Various logistics cost components have been proposed in the Supply Chain Management literature, varying from one publication to another. Among these publications, we will mention that of [8] who conducted a survey of 1068 Irish companies and that of [9] since several studies refer to the concept of total cost developed by these authors [3]. Of the survey respondents, $28.3 \%$ agreed that transport / freight / deliveries should be included in logistics costs. The job / salary were supported by $17 \%$ of respondents, while $16 \%$ admitted that materials should be included. A group of "Other costs" is included at $10.4 \%$; the storage is $8.5 \%$ while the inventory is $6.6 \%$. In addition, procurement, production, and administration were identified by less than $5 \%$ of respondents, respectively. While the approach proposed by Lambert, Grant, Stock and Ellram identifies six main cost groups:

- Customer service level. One of the major costs at this level is the cost of lost sales. Another example in this category is the cost of returned goods.
- Transport costs. The revised transport cost literature includes transportation, consolidation (cost of small shipments), transfer (mode of transportation), pick-up and delivery, and the cost of pilfering or damage during transport [10]. Weber discusses transportation costs in detail and distinguishes between internal (for example, transport from one warehouse to another) and external transport; Transport for own account and others; and regular transportation or as needed. Further examination by mode of transportation may be necessary [11]. The main factors that affect transportation costs can be divided into:

$\checkmark$ Distance (the transport cost elasticity over distance are 0.46 (air), 0.39 (rail), 0.275 (road) and 0.22 (maritime) [12] and geography (the landlocked countries face a major cost disadvantage).

$\checkmark$ Infrastructure and trade facilitation. Investment in infrastructure, although expensive to undertake, has a major impact in reducing transport costs. Wilson argues that the average waiting time at a border could have been used to cover $1600 \mathrm{~km}$ inland [13]. This may be due to physical infrastructure issues such as ports, but also due to procedural delays.

$\checkmark$ Market power. For transportation services as derived demand, Hummels, Lugovskyy, and Skiba state that transportation prices are higher if there is a low elasticity of demand and the greater the number of shippers increases, the price and the impact of the elasticity decrease [14].

- Warehousing costs are generated by warehousing and storage activities, as well as warehouse location costs.

- Inventory costs can be divided into four categories, namely capital or opportunity costs, inventory service costs, storage costs and inventory risk costs [15].

- Quantities of supply and production. These costs include installation costs, lost capacity (for example when changing the tool) and material management.

- Processing costs and information systems those are related to activities such as order processing, communications and forecasting.

\section{B. Logistics cost components by cost type}

Another way of classifying logistics costs is by cost type. This corresponds to the accounting perspective. Cost information is likely to be classified in the accounts of many companies in this way. However, sorting out the logistics part in the account can be difficult, according to the organization [16].

- Cost of personnel or manpower constitutes probably a big part of the logistics, whether in the purely operational logistics task in the warehouse or in the logistics administration.

- Cost of facilities includes buildings used for logistical activities, rented or detained. The cost of the land can be included in this category or be a distinct element.

- Equipment includes shelves, forklifts, pallets and other equipment used for logistics operations.

- Computer systems and computers may be part of the previous group, or be in a separate category. 
- Cost of operation include items such as fuel, electricity, water, maintenance, insurance, telephone charges, printing and photocopying, etc.

- Amortization of logistics assets (buildings, machinery and the transport fleet) which represents an expense influencing the declaration of losses / benefits.

\section{LEVEL OF LOGISTICS COSTS ASSESSEMENT}

The notion of logistic performance and more precisely the cost can be analyzed at different levels: from the microeconomic point of view, the notion comes under the discipline of management sciences; from a macroeconomic point of view, the analysis focuses on the logistic performance of firm systems (national, regional, sectoral)

\section{A. 'Macro' Level}

The macro approach examines national accounts and measures the contribution of the logistics sector to GDP. This approach therefore gives an overview of the relative size of the sector. Nevertheless, it does not provide an unambiguous performance indicator since the relationship between sector size and logistic performance is non-monotonic [17]. Similarly, there is no systematic relationship between the sector's contribution to GDP and economic outcomes [18]

Three main measures are used for the assessment of logistics costs at the national level, namely the \% of sales or turnover, absolute costs and \% of GDP [19].The OECD defines turnover as the total amount invoiced by the observation unit during the reference period. Sales, meanwhile, are defined as operating revenues minus discounts, returns and sales taxes on consumers. In general, these two definitions basically mean the same thing, with some minor differences regarding the inclusion or exclusion of value added tax (VAT). While absolute cost represents the ability of a country, individual, firm or region to produce a good or service at a unit cost lower than the cost of any other entity producing the same good or service.

\section{B. 'Micro'" Level}

Micro-analysis of sectors, products / services and supply chains makes it possible to compare logistics costs with the final value of products / services, identify areas of inefficiency, and offer more competitive prices.
Metrics used to estimate logistics costs at this level are diverse. According to Supply Chain Digest's survey of 247 representatives from several industries in 2006, $40 \%$ use sales as the main measure of logistics costs, while $25 \%$ consider absolute costs as their main measure. The remaining respondents based their measurements on weight, sales unit or activity-based accounting [19].

\section{MAIN METHODS OF LOGISTICAL COSTS ASSESSEMENT}

The techniques used to evaluate costs at the micro level do not directly provide the type of information needed to assess costs at the macro level. It is important, however, to understand the basics of cost accounting techniques employed by firms, as survey participants (for macro-level costing) can use this information in their responses.

\section{A. Logistics Costs Assessment Methods of the "Macro" Level}

Several methods and tools are used to conduct a study on logistics costs at the macro (national) level. These methods differ according to the availability of data and the reliability of statistical sources. They are grouped into three categories: surveys that collect empirical data directly from respondents, studies based on statistics that create a model by combining existing data from different statistical sources, and case studies and other studies that include studies conducted with a case study methodology and studies that cannot be classified either among those based on statistics or surveys.

\section{1) Studies based on surveys}

Surveys typically use questionnaires to collect data on logistics costs from respondents. A significant difference between this approach and that based on the statistics comes from Supply Chain angle view.

While statistics-based studies usually address the "Supply" side of the chain, surveys are usually conducted with stakeholders and are interested in the "Demand" perspective. Studies at this level are divided into Multi-Country (MC) and Single Country (SC) studies. Several cost components are treated namely Transport (T), Warehousing (E), Administration (A), Inventory (I), Transport Packaging (TP) and Other Cost $(\mathrm{O})$ ( See table 1).

TABLE I. EXAMPLES OF QUESTIONNAIRE SURVEYS

\begin{tabular}{|c|c|c|c|c|c|c|c|c|c|}
\hline & \multirow{2}{*}{ Definition } & \multicolumn{2}{|c|}{ Areas } & \multicolumn{6}{|c|}{ Costs components } \\
\hline & & $\mathrm{MC}$ & $\mathrm{SC}$ & $\mathrm{T}$ & $\mathrm{E}$ & $\mathrm{A}$ & I & $\mathrm{O}$ & $\mathrm{TP}$ \\
\hline SCI 2011 & $\begin{array}{l}\text { Conducted by SCI Verkehr, which publishes a monthly logistic barometer analyzing logistics } \\
\text { indicators selected by } 200 \text { managers in the transport and logistics sectors. }\end{array}$ & & $\mathrm{x}$ & & & & & & \\
\hline $\begin{array}{l}\text { Davis } \\
2010\end{array}$ & $\begin{array}{l}\text { Maintained by Establishment Management Consultants specializing in the supply chain. It's an } \\
\text { ongoing survey that allows companies primarily in the United States to compare their logistics } \\
\text { costs and service level. }\end{array}$ & $\mathrm{X}$ & & $\mathrm{x}$ & $\mathrm{x}$ & $\mathrm{x}$ & $\mathrm{x}$ & & \\
\hline $\begin{array}{c}\text { Finland } \\
2010\end{array}$ & $\begin{array}{l}\text { In Finland State of Logistics } 2012 \text {, the distribution of respondents based on the industry was: } \\
\text { manufacturing and construction } 32 \% \text {, trading } 28 \% \text {, LSP } 25 \% \text {, consulting } 5 \% \text { and education } 10 \% \text {. }\end{array}$ & $\mathrm{X}$ & $\mathrm{x}$ & $\mathrm{x}$ & $\mathrm{x}$ & $\mathrm{x}$ & $\mathrm{x}$ & $\mathrm{x}$ & $\mathrm{x}$ \\
\hline $\begin{array}{l}\text { ELA } \\
2009\end{array}$ & $\begin{array}{l}\text { European Logistics Association (ELA) is a coalition of } 30 \text { national organizations covering most } \\
\text { Western and Central European countries since } 1982 \text {. }\end{array}$ & $\mathrm{X}$ & $\mathrm{x}$ & $\mathrm{x}$ & $\mathrm{x}$ & & & & \\
\hline $\begin{array}{l}\text { Aslog } \\
2009\end{array}$ & $\begin{array}{l}\text { The aim is to assess the state of logistics in France and gather information to create measures that } \\
\text { would allow logistic costs to be compared with other countries. }\end{array}$ & $\mathrm{X}$ & $\mathrm{x}$ & $\mathrm{x}$ & & & & & \\
\hline $\begin{array}{l}\text { Japan } \\
2007\end{array}$ & $\begin{array}{l}\text { The Japan Institute of Logistics Systems (JIL) maintains a national database for transport and } \\
\text { logistics developments. }\end{array}$ & $\mathrm{X}$ & $\mathrm{x}$ & & & $\mathrm{x}$ & & & \\
\hline
\end{tabular}




\section{2) Studies based on statistics}

These studies use statistical data, models and methods to calculate the level of logistics costs (Transport (T), Warehousing (E), Administration (A), Inventory (I), Transport Packaging (PT), Cargo Processing (CP), Communication (C), Customer Service (CS), Documentation (D), Equipment (Eq), Information (In), Insurance (As)) in several countries or at one country level (see table 2). Models created by statistical studies can be of three types [20]: econometrics that presents the phenomenon as a network of causal relationships between internal and external variables, analytic that uses mathematical manipulation to find a solution to the problem or by simulation that seeks to present the behavior of complex phenomena over long periods of time according to real-world models.

It should be noted that the distinct difference between case studies (which may also use statistics) and statistical studies is that the latter uses a well-established and verified model.

\begin{tabular}{|c|c|c|c|c|c|c|c|c|c|c|c|c|c|c|c|}
\hline & \multirow{2}{*}{ Definition } & \multicolumn{2}{|c|}{ Area } & \multicolumn{12}{|c|}{ Costs components } \\
\hline & & $\mathrm{MC}$ & $\mathrm{Sc}$ & $\mathrm{T}$ & $\mathrm{A}$ & $\mathrm{I}$ & $\mathrm{E}$ & $\mathrm{CP}$ & PT & $\mathrm{C}$ & $\mathrm{CS}$ & $\mathrm{D}$ & $\mathrm{Eq}$ & In & As \\
\hline $\begin{array}{l}\text { South } \\
\text { Africa } \\
2011\end{array}$ & $\begin{array}{l}\text { Produced by the Council for Scientific and Industrial Research (CSIR), } \\
\text { the model uses data on the mode of transport, tonnage transported and } \\
\text { stored, transport distances and costs, and transport time. }\end{array}$ & & $\mathrm{x}$ & $\mathrm{x}$ & $\mathrm{x}$ & $\mathrm{x}$ & $\mathrm{x}$ & & & & & & & & \\
\hline $\begin{array}{l}\text { Korea } \\
2010\end{array}$ & $\begin{array}{l}\text { The Korea Transport Institute (KOTI) provided macroeconomic estimates } \\
\text { by assessing various logistics cost factors. }\end{array}$ & & $\mathrm{x}$ & $\mathrm{x}$ & $\mathrm{x}$ & $\mathrm{x}$ & & $\mathrm{x}$ & $\mathrm{x}$ & & & & & $\mathrm{x}$ & \\
\hline $\begin{array}{l}\text { Thailand } \\
2009\end{array}$ & $\begin{array}{l}\text { The Office of the National Council for Economic and Social } \\
\text { Development has developed a model and database to publicize the } \\
\text { country's official logistics. }\end{array}$ & & $\mathrm{x}$ & $\mathrm{x}$ & $\mathrm{x}$ & $\mathrm{x}$ & & & & & & & & & \\
\hline $\begin{array}{l}\text { Canada } \\
2008\end{array}$ & $\begin{array}{l}\text { Industry Canada has launched a project dedicated to the creation of a } \\
\text { Logistics Costing Toolbox. The toolbox defines three cost components } \\
\text { and classifies cost activity categories and related components. }\end{array}$ & $\mathrm{x}$ & & & & $\mathrm{x}$ & & & & & & & & & \\
\hline $\begin{array}{l}\text { Morocco } \\
2006\end{array}$ & $\begin{array}{l}\text { Trade Logistics and Competitiveness in Morocco } 2006 \text { was jointly } \\
\text { launched by the World Bank Group and the Ministry of Transport in } \\
\text { Morocco. The study is a combination of previous research findings, } \\
\text { national statistics, national accounts, and multi-stakeholder hearings } \\
\text { across different industries, government agencies, and export and import } \\
\text { organizations. An analysis was conducted among the industries } \\
\text { considered important for the Moroccan economy, including the } \\
\text { automotive, electronics, textile and fruit and grocery industries. }\end{array}$ & & $\mathrm{x}$ & $\mathrm{x}$ & $\mathrm{x}$ & $\mathrm{x}$ & $\mathrm{x}$ & $\mathrm{x}$ & $\mathrm{x}$ & $\mathrm{x}$ & $\mathrm{x}$ & $\mathrm{x}$ & $\mathrm{x}$ & & $\mathrm{x}$ \\
\hline
\end{tabular}

\section{3) Case studies}

Case studies are usually used where sufficient statistics are not available and it is not possible to conduct an investigation.

Examples of the case studies are given by the table 3 .

TABLE III _ EXAMPLES OF CASE STUDIES

\begin{tabular}{|c|c|c|}
\hline & Definition & Costs components \\
\hline World Bank & $\begin{array}{l}\text { Among several studies of the World Bank, we find } \\
\text { that proposed by [21].which proceeds by a different } \\
\text { grouping of logistics costs. This is mainly due to the } \\
\text { subject of their study, which examines logistics costs } \\
\text { in landlocked countries. }\end{array}$ & $\begin{array}{l}\text { Authors evaluate the level of logistics costs by measuring transit } \\
\text { transport. In their group, total logistics costs also include three } \\
\text { components: transportation costs, other logistical costs, and } \\
\text { lagging coverage costs. }\end{array}$ \\
\hline $\begin{array}{l}\text { UK Logistics } \\
\text { Report } 2011\end{array}$ & $\begin{array}{l}\text { Published by the Freight Transport Association } \\
\text { (FTA) of the United Kingdom. The report uses data } \\
\text { from a variety of sources, the most important being } \\
\text { the 2010/11 FTA Logistics Industry Survey. }\end{array}$ & $\begin{array}{l}\text { The study divides logistics costs into four key areas: wages, } \\
\text { vehicle operation, storage and transportation. }\end{array}$ \\
\hline $\begin{array}{l}\text { Understanding } \\
\text { transportation } \\
\text { costs and charges } \\
2010\end{array}$ & $\begin{array}{l}\text { The case study is undertaken by the Ministry of } \\
\text { Transport in New Zealand }\end{array}$ & $\begin{array}{l}\text { The total logistics costs were divided into direct transport costs } \\
\text { (international / domestic movements, mode transfers), indirect } \\
\text { transport costs (port costs, customs / biosecurity, insurance) and } \\
\text { other costs (packaging, storage, inventory, loss). inventory, } \\
\text { administration, information systems) }\end{array}$ \\
\hline $\begin{array}{l}\text { Formulation of } \\
\text { regional logistics } \\
\text { policy: case of } \\
\text { Asia, } 2008\end{array}$ & $\begin{array}{l}\text { [22] discuss, among other things, logistics costs in } \\
\text { the Asian region, covering Brunei, Cambodia, } \\
\text { Indonesia, the Lao People's Democratic Republic, } \\
\text { Malaysia, Myanmar, the Philippines , Singapore, } \\
\text { Thailand and Vietnam }\end{array}$ & $\begin{array}{l}\text { The results of the study are based on seven questionnaires related } \\
\text { to logistics activities in the following sectors: customs, ports and } \\
\text { maritime transport, rail, road, river and air transport as well as } \\
\text { logistics services. }\end{array}$ \\
\hline $\begin{array}{l}\text { (Hausman, Lee } \\
\text { and Subramanian, } \\
\text { 2005) }\end{array}$ & $\begin{array}{l}\text { Logistics indicators have been studied by [23], which } \\
\text { examined the effect of logistics costs and time on } \\
\text { bilateral trade relations. The study uses global } \\
\text { logistics indicator data from } 80 \text { economies to create a } \\
\text { three-step estimation process and logistic index, } \\
\text { which would include several logistic indicators. }\end{array}$ & $\begin{array}{l}\text { Authors apply the total landed cost model, which includes the } \\
\text { following components of logistics cost: } \\
\text { - Shipping costs (shipping). } \\
\text { - Trade-related costs (processing, customs clearance, port } \\
\text { operations). } \\
\text { - Inventory costs for inventory in transit. } \\
\text { - Inventory costs for security stocks inventory. }\end{array}$ \\
\hline
\end{tabular}




\section{B. Logistics Costs Assessment Methods of the "Micro "} Level

Rantasila classifies the most commonly used techniques and tools for calculating logistic costs at a micro level, according to their rates of adaptation by different links in the Supply Chain [3]. The three links identified by the author are the intra-company, the upstream of the company, and the downstream of the company. It should be noted that this grouping is not exhaustive and that some tools can be used at different stages of the supply chain.

\section{1) Logistics costs Assessment Methods within the company}

Intra-company costing tools focus on measuring performance, primarily internal functions of the company. The table presents the most commonly used costing tools in the intra-firm context, provides a brief description of each tool, indicates some of its objectives and indicates an example of application of the tool in question.

TABLE IV. LOGISTICS COSTS ASSESSMENT METHODS WITHIN THE COMPANY

\begin{tabular}{|c|c|c|c|}
\hline & Description & Objective & Application examples \\
\hline $\begin{array}{l}\text { Activity } \\
\text { Based } \\
\text { Costing } \\
\text { and its } \\
\text { derivatives } \\
\text { (ABC) }\end{array}$ & $\begin{array}{l}\text { Assign direct and indirect costs to } \\
\text { activities that consume resources. } \\
\text { Then, combine the costs with the } \\
\text { resources used. This method can be } \\
\text { applied also to upstream and } \\
\text { downstream of the company }\end{array}$ & $\begin{array}{l}\text {-Decision making, } \\
\text { outsourcing and profitability } \\
\text { analysis } \\
\text { - Information on cost } \\
\text { elements }\end{array}$ & $\begin{array}{l}\text { Baykasoglu, and Kaplanoglu presented an a } \\
\text { method in a transport company located in } \mathrm{T} \\
\text { effectiveness of ABC, an integrated approac } \\
\text { Business Process Modeling and the Analytical } \\
\text { is proposed. They argued that the proposed ap } \\
\text { than the traditional cost system in calculating } \\
\text { ground transportation services [24]. }\end{array}$ \\
\hline & $\begin{array}{l}\text { nce from four } \\
\text { ancial, customer, } \\
\text { process, and } \\
\text { g }\end{array}$ & $\begin{array}{l}\text { - Performance measurement } \\
\text { - Evaluation of customer } \\
\text { service, suppliers, Third- } \\
\text { Party Logistics (3PL) and } \\
\text { financial performance, etc. }\end{array}$ & $\begin{array}{l}\text { ies for } \\
\text { ategies } \\
\text { fferent } \\
\text { ies are }\end{array}$ \\
\hline $\begin{array}{l}\text { E } \\
\text { V } \\
\text { A } \\
(\mathrm{B}\end{array}$ & $\begin{array}{l}\text { generated by the } \\
\text { icting the capital } \\
\text { erating income. }\end{array}$ & $\begin{array}{l}\mathrm{n} \text { of non- } \\
\text { nation into } \\
\text { tion } \\
\text { eated value }\end{array}$ & $\begin{array}{l}f \text { the } \\
\mathrm{g} \text { and } \\
\mathrm{n} \text { the }\end{array}$ \\
\hline $\begin{array}{l}\mathrm{Kai} \\
\mathrm{Co}\end{array}$ & $\begin{array}{l}\text { ms to reduce costs in the } \\
\text { duction phase }\end{array}$ & $\begin{array}{l}\text { - Reducing product costs } \\
\text { currently in production }\end{array}$ & $\begin{array}{l}\text { Baykasoglu a } \\
\text { service cost }\end{array}$ \\
\hline $\begin{array}{l}\text { Sta } \\
\text { Cos }\end{array}$ & $\begin{array}{l}\text { velops standard costs for } \\
\text { vities that are deemed to be met. }\end{array}$ & $\begin{array}{l}\text { - Cost control } \\
\text { - Simplification of act }\end{array}$ & these systems \\
\hline
\end{tabular}

Sources: Improvement of [29].

2) Logistic costing methods upstream of the enterprise Unlike the previous table, the table 5 presents cost analysis tools focused on measuring the upstream level of the supply chain (inbound functions).

TABLE V. LOGISTICS COSTS ASSESSMENT METHODS UPSTREAM THE COMPANY

\begin{tabular}{|c|c|c|c|}
\hline & Des & Objective & \\
\hline $\begin{array}{l}0 \\
\sum_{0} \\
\omega \\
0 \\
0 \\
\frac{1}{0} \\
0 \\
0\end{array}$ & $\begin{array}{l}\text { igns costs of non-production to a } \\
\text { nt and to root causes in order to } \\
\text { rmine the total cost }\end{array}$ & $\begin{array}{l}\text { - Estimation of the } \\
\text { client's profitability } \\
\text { - Network } \\
\text { optimization } \\
\text {-Inventory Level } \\
\text { Decisions }\end{array}$ & $\begin{array}{l}\text { Ross, Jayaraman, and Robinson attempted to optimize the service of a 3PL } \\
\text { using the CTS method. The aim is to use the method to identify the relevant } \\
\text { cost drivers of 3PL services, in a research-action approach that identifies } \\
\text { relevant operational constraints and then use the action research framework } \\
\text { and the CTS to model different cost elements that could be incorporated } \\
\text { into the objective function of a mathematical programming model [30]. }\end{array}$ \\
\hline 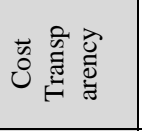 & $\begin{array}{l}\text { Share information about internal costs } \\
\text { with suppliers (expandable } \\
\text { downstream method that helps to } \\
\text { share information with customers) }\end{array}$ & $\begin{array}{lr}\text { Cost } & \text { savings } \\
\text { through } & \text { joint } \\
\text { development } \\
\cdot \text { Exchange of ideas }\end{array}$ & $\begin{array}{l}\text { decision } \\
\text { acilitates }\end{array}$ \\
\hline 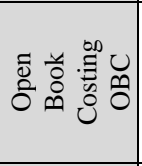 & $\begin{array}{l}\text { Supplier provides cost structure } \\
\text { information to the customer and, in } \\
\text { return, the customer helps the supplier } \\
\text { to reduce costs (Not expandable to } \\
\text { downstream level) }\end{array}$ & $\begin{array}{l}\text { - Supply decisions, } \\
\text { cost reduction } \\
\text { Performance Vendor } \\
\text { Assessment, 3PL. }\end{array}$ & oplier dyad, appropriate incenti \\
\hline 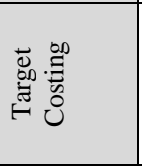 & $\begin{array}{l}\text { Method for new products that } \\
\text { determines customer needs. It uses } \\
\text { upstream information to adjust } \\
\text { downstream functions. The method } \\
\text { can be used also in downstream. }\end{array}$ & $\begin{array}{l}\text { uction } \\
\text { change on } \\
\text { m }\end{array}$ & $\begin{array}{l}\text { Baykasoglu, A., Kaplanoglu, in their study have attempted to provide a } \\
\text { service costing framework for logistics companies that provide } \\
\text { international land transport by truck. The framework includes three } \\
\text { methods: ABC, Kaizen Costing and Target Costing [27]. }\end{array}$ \\
\hline 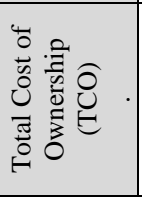 & $\begin{array}{l}\text { Determine the total cost of a certain } \\
\text { acquisition by associating all the costs } \\
\text { of the supply with the returns. This } \\
\text { means that the tool examines costs } \\
\text { throughout the supply chain }\end{array}$ & $\begin{array}{l}\text { - Assessment of } \\
\text { supply sources. } \\
\text { - Measurement of } \\
\text { total costs of a } \\
\text { certain acquisition. } \\
\cdot \text { Purchase decisions. }\end{array}$ & $\begin{array}{l}\text { Degraeve, Labro, and Roodhooft in their paper, developed a mathematical } \\
\text { programming model that selects multi-service object providers and } \\
\text { simultaneously determines the market shares of selected suppliers. The } \\
\text { methodology is based on information gathering by the method (TCO), } \\
\text { quantifying all the costs associated with the purchasing process across the } \\
\text { entire value chain of the company [33]. }\end{array}$ \\
\hline
\end{tabular}

Sources: Improvement of [29] 
3) Logistic costing methods downstream of the enterprise Similarly to the previous table 6 , the table presents the logistics costing tools, but this time at the downstream level of the supply chain (outgoing functions).

TABLE VI. TABLE 6. LOGISTICS COSTS ASSESSMENT METHODS UPSTREAM THE COMPANY

\begin{tabular}{|c|c|c|c|}
\hline & Description & Objective & Application examples \\
\hline $\begin{array}{l}\text { Customer } \\
\text { Profitability } \\
\text { Analysis } \\
\text { (CPA) }\end{array}$ & $\begin{array}{l}\text { Allocate revenues and } \\
\text { costs at the end of the } \\
\text { supply chain to } \\
\text { determine profitability. }\end{array}$ & $\begin{array}{l}\text { - Determining the profitability of a } \\
\text { customer or a segment } \\
\text { - Reallocation of resources } \\
\text { - Cost reduction } \\
\text { - Network optimization } \\
\text { - Production programming } \\
\text { - Inventory Level Decisions }\end{array}$ & $\begin{array}{l}\text { Raaijand and his colleagues at the level of the realized article, the } \\
\text { process of CPA implementation is illustrated with the help of a } \\
\text { case study in a company producing and selling professional } \\
\text { cleaning products. The study highlights specific issues related to } \\
\text { CPA in an industrial context and the results provided examples and } \\
\text { possible benefits of implementing a regular CPA process [34]. }\end{array}$ \\
\hline $\begin{array}{l}\text { Life Cycle } \\
\text { Costing } \\
\text { (LCC) }\end{array}$ & $\begin{array}{l}\text { Involves all costs } \\
\text { associated with a } \\
\text { system or product } \\
\text { during its lifetime. The } \\
\text { technique can be } \\
\text { extended to the supply } \\
\text { side. }\end{array}$ & $\begin{array}{l}- \text { Reduce costs of upstream functions } \\
\text { - Providing information on all stages of } \\
\text { the supply chain for decision-making }\end{array}$ & $\begin{array}{l}\text { Kjaer and his colleagues proposed an environmental input / output } \\
\text { model used for the analysis because it allows a Life Cycle analysis } \\
\text { LCA to use the same economic input data as LCC. This approach } \\
\text { aligns LCA and LCC while avoiding cuts in LCA. The efficiency } \\
\text { of the method is illustrated by a real case study of a tanker [35]. }\end{array}$ \\
\hline $\begin{array}{l}\text { Landed } \\
\text { Costing }\end{array}$ & $\begin{array}{l}\text { Captures activity costs } \\
\text { to move the product to } \\
\text { the final destination. } \\
\text { Includes freight, } \\
\text { handling, etc. }\end{array}$ & $\begin{array}{l}\text { - Provides information for the selection } \\
\text { of logistics service providers } \\
\text { - Network optimization and } \\
\text { outsourcing decisions } \\
\text { - Reorganization of processes }\end{array}$ & $\begin{array}{l}\text { The objective of the research conducted by [36] is to create a } \\
\text { framework to accurately assess the benefits of Hub capacity in an } \\
\text { international distribution network for packaged products }\end{array}$ \\
\hline
\end{tabular}

As mentioned above, grouping tables is not absolute. Some of the tools can be implemented, at least with minor changes, in different parts of the supply chain. The figure 1 positions all tools in two classification dimensions (optimization / analysis, upstream / intra / downstream) [3].

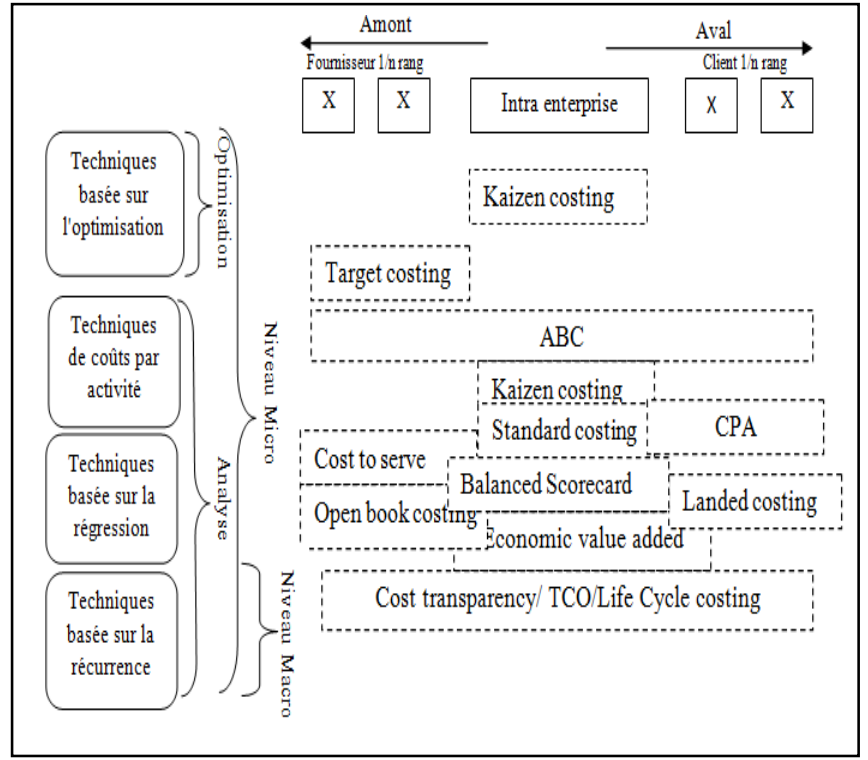

Fig. 1. Classification of Supply Chain Costing Tools Source: Adopted from [3]

\section{CONCLUSION}

Assessing the performance of logistics at the country level is of great importance as it helps to focus efforts made in transport and trade facilitation which contributes to improving the efficiency of supply chains and the functioning of infrastructures, services, procedures and regulations in connection with these chains [19]. At the supply chain level, better information on the logistics costs and chain management activities can help managers making better decisions. Besides, insufficient information about these costs can hinder the negotiation and the cooperation between Supply chain partners [16].

Logistic costs at the micro level are generally assessed by accounting approaches. These approaches, in their traditional version, do not support inter-organizational decisions. While contemporary ones, though they overcome some of the shortcomings of traditional accounting practices, they cannot address all the problems they face in an inter-organizational context. A combination of several methods, depending on the purpose of the implementation, will cover these failures.

At the Macro level, logistics costs are usually handled in one country via multi-thematic studies. These studies are often in the form of a case study. It should be noted that methods based on surveys and statistics tend to be more reliable if they are applicable [3].

\section{REFERENCE}

[1] R.Z. Farahani, N. Asgari, H. Davarzani, Supply Chain and Logistics in National, International and Governmental Environment- Concepts and Models. Physiga-Verlag, Berlin, Germany, 2009

[2] I., Themido, A. , Arantes, C., Fernandes, and A.P. , "Guedes, Logistic costs case study - an ABC approach" , Journal of Operational Research Society, vol. 51, pp. 1148-1157, 2000.

[3] K. Rantasila, Measuring logistics costs Designing a generic mode for assessing macro logistics costs in a global context with empirical evidence from the manufacturing and trading industries, Publications of Turku School of Economics, Series A. 2013,

[4] T. Pohlen, Klammer, T. Cokins, G., The Handbook of Supply Chain Costing, Lombard, Illinois, USA. 20090

[5] P. Dimitrov, National Logistics Systems. Publications of Institute for Applied Systems Analysis, CP-91-06, Laxemburg, Austria, 1991.

[6] A. Rushton , P. Croucher, B. ,Baker, Handbook of Logistics and Distribution Management. 3rd edition. Kogan Page. Glasgow, UK. 2006

[7] T., Davis, "E!ective supply chain management", Sloan Management Review, Vol.12, pp.35- 46, 1993

[8] A. Smith, B. Huber, Comparative Challenges: Chain Reactions: an Analysis of Supply Chain Management and Competitive Solutions for the Island of Ireland. National Institute of Transport Logistics, Dublin, Ireland, 2005

[9] D. Lambert, D. Grant, J. Stock, L. Ellram, Fundamentals of Logistics Management. European edition. McGraw-Hill, Maidenhead, Berkshire, UK, 2006 
[10] A.Z. Zeng, C.Rossetti, "Developing framework for evaluating the logistics cost in global sourcing process: An implementation and Insights", International Journal of Physical Distribution \& Logistics Management, Vol. 33, No. 9, pp. 785-803. 2003

[11] J. Weber, Logistikkostenrechnung: Kosten-, Leistungs- und Erlösinformationen zur erfolgsorientierten Steuerung der Logistik. 2. Auflage. Springer-Verlag: Berlin. 2002,

[12] D. Hummels, Time as a trade barrier, GTAP Working Papers No. 1152, Center for Global Trade Analysis, Department of Agricultural Economics, Purdue University, 2001.

[13] J. Wilson, Trade facilitation: new issues in a development context, Trade note No. 12. World Bank, Washington DC. 2003,

[14] D. Hummels, V. Lugovskyy, A. Skiba, "The trade reducing eff ects of market power in international shipping “, Journal of Development Economics, vol.89, pp.84-97. 2009.

[15] A. Fröderberg, Cutting Logistics Costs with a Centralized Distribution Model for ABB's Distribution of LV Products in Asia Pacific, Luleå University of Technology, Master's Thesis 2006:217, Luleå, Sweden. 2006,

[16] H.M. Hälinen, Understanding the concept of logistics cost in manufacturing, Publications of Turku School of Economics, Series A. , 2015

[17] A. Bárcena, E. García, E. Gurría, Latin American Economic Outlook 2014 logistics and competitiveness for development, OECD/UN- ECLAC/CAF. 2014,

[18] B. Shepherd, Logistics costs and competitiveness: Measurement and trade policy applications, MPRA Paper, No. 38254, University Library of Munich, Germany, 2001

[19] K. Rantasila, L. Ojala, "The Measurement of National-Level Logistics Costs and Performance “, International Transport Forum's Discussion, No.-4, OECD, 2012.

[20] L. Ojala, Modelling Approaches in Port Planning and Analysis. Publications of the Turku School of Economics and Business Administration, Series A-4:1992, Turku, Finland, (1992)

[21] J.F Arvis, G.Raballand, J.J. Marteau, The Cost of Being Landlocked: Logistics Costs and Supply Chain Reliability, World Bank Policy Research Working, 2007

[22] R.Banomyong, P.Cook, P.Kent, "Formulating Regional Logistics Development Policy: The Case of ASEAN", International Journal of Logistics: Research and Applications, Vol. 11, Iss.5, pp.359-379, 2008.

[23] W. Hausman, H. Lee, U. Subramanian, Global Logistics Indicators, Supply Chain Metrics and Bilateral Trade Patterns (World Bank Policy Research Working Paper 3773). <http://www.worldbank.org/external/default/WDSContentServer/WD SP/IB/2005/11/17/000016406_20051117161830/Rendered/PDF/wps3 773.pdf $>2005$,

[24] A.Baykasoglu, V. Kaplanoglu, "Application of activity-based costing to a land transportation company: A case study", Int. J. Production Economics, vol. 116, pp. 308-324, 2007.

[25] R.S Rajesh, K. Pugazhendhi, K., Y. Ganesh, S.C. Ducq, LennyKoh, "Generic balanced scorecard framework for third party logistics service provider", Int. J. Production Economics, vol. 140, pp 269282. 2012

[26] L.M. Austin, "Benchmarking to economic value added The case of Airways Corporation of New Zealand Limited, Benchmarking", An International Journal, Emerald Group Publishing Limited, Vol. 12 No. 2, pp. 138-150, 2005.
[27] A., Baykasoglu , V., Kaplanoglu, 2007, "A service-costing framework for logistics companies and a case study", Managemen Research News, Vol. 30, Iss 9 pp. 621 - 633,2007

[28] A., Hatzis, A., Koulidou, et Folinas, D., Costing Logistics Services, 1st Olympus International Conference on Supply Chains, Greece, 2010.

[29] T., Pohlen, T. Klammer, G., Cokins, The Handbook of Supply Chain Costing, Lombard, Illinois, USA, 2009.

[30] A., Ross, V. Jayaraman, et P., Robinson, "Optimizing 3PL service delivery using a cost-to-serve and action research, framework", International Journal of Production Research, Vol.45, Iss.1, pp.83$101,2014$.

[31] O., Schneider, et I., Lange, Service Operating Cost Transparency in Customer and Supplier Relationships, Exploiting the knowledge Eonomy: Issues, Application and Case studies, P. Cunnimgham and M. Cunnimgham, IOS Press, 2006.

[32] P., Romano, et M., Formentini, ”Designing and implementing open book accounting in buyer-supplier dyads: A framework for supplier selection and motivation", International Journal of Production Economics, Vol. 137, Iss.1, pp. 68-83, 2012.

[33] Z., Degraeve, E., Labro, F., Roodhooft , "Total cost of ownership purchasing of a service: The case of airline selection at Alcatel Bell", European Journal of Operational Research, vol.156 , pp. 23-40, 2004,

[34] E. M. van, Raaij, M. J.A., Vernooij, et S., Van Triest, "The implementation of customer profitability analysis: A case study", Industrial Marketing Management, Vol.32, Iss. 7, pp. 573-583,2003.

[35] L.L, Kjaer, A., Pagoropoulos, M., Hauschild, M., Birkved, J.H, Schmidt, et T.C., McAloone, "From LCC to LCA using a hybrid Input Output model -a maritime case study",Procedia CIRP, pp.474479, 2015.

[36] S. O., Duran, et R., Hawks,Analysis of an international distribution hub for fast moving consumer goods, Degree of Master of Engineering in Logistics, 2009.

[37] ELA homepage, About us. <http://www.elalog.org/>, accessed Nov 13th 2009.

[38] ASLOG L'état de l'art de la logistique française. <http://www.aslog. org/fr/ACTU_historique.php?niv2=31\&id_actu=315>, accessed Jan 20 th 2010.

[39] KOTI, 2010, Korean Macroeconomic Logistics Costs in 2008 http://english.koti.re.kr/board/report/download.asp?code=research_re port\&record_idx=1440\&type=normal

[40] SCM and KPI Analysis - A Canada / United States Retail Perspective 2006.http://www.ic.gc.ca/eic/site/dsiblogi.nsf/vwapj/pg00017_eng.pd f/\$file/pg00017_eng.pdf

[41] La Logistique du Commerce et la Compétitivité du Maroc 2006 http://www.mtpnet.gov.ma/Morocco\%20trade\%20logistics\%20Final \%20May\%2030\%202006.PDF

[42] The Logistics Report 2011 UK (2011) available at http://www.fta.co.uk/export/sites/fta/_galleries/downloads/logistics_r eport/logistics_report_2011.pdf

[43] Ministry of Transport in New Zealand, 2010, Understanding Transport Costs and Charges - Transport costs in freight logistics available <http://www.transport.govt.nz/research/Documents/UTCC-Phase-2Transport-and-freight-logistics-final-report-Nov2010.pdf $>$ 